\title{
Draft Genome Sequence of Staphylococcus felis HARRANVET Strain
}

\author{
Özkan Aslantaş ${ }^{1}$, Oktay Keskin², Kaan Büyükaltay ${ }^{3}$, Ayfer Güllü Yücetepe ${ }^{2}$
}

${ }^{1}$ Department of Microbiology, Faculty of Veterinary Medicine, Hatay Mustafa Kemal University, Hatay/TURKEY

${ }^{2}$ Department of Microbiology, Faculty of Veterinary Medicine, Harran University, Sanliurfa/TURKEY

${ }^{3}$ Bionformatics Institute, Middle East Technical University, Ankara/TURKEY

Key Words:
cat
Staphylococcus felis
whole-genome sequencing
Anahtar Kelimeler:
kedi
Staphylococcus felis
tüm genom dizileme

Received $\quad: 22.02 .2021$
Accepted $\quad: 07.04 .2021$
Published Online : 31.08 .2021
Article Code $: 884932$

Correspondence:

Ö. ASLANTAS

(aslantas@mku.edu.tr)

ORCID:

Ö. ASLANTAS

O. KESKIN

K. BÜYÜKALTAY

0000-0003-0407-8633

0000-0002-5977-7872

0000-0001-6074-8940

A. GÜLLÜ-YÜCETEPE : 0000-0002-9842-3305

\begin{abstract}
Staphylococcus felis is one of staphylococci residing on skin of cats, and has been increasingly reported as a potential facultative pathogen. A recently isolated Staphylococcus felis(named as S. felis HARRANVET strain) from necrotizing fasciitis case of a cat was characterized using wholegenome sequencing (WGS), and assembled genome was in silico screened for putative virulence and antimicrobial resistance genes. The isolate was pan-susceptible to all antimicrobials tested, indicated absence of resistance genes. A limited number of virulence genes associated with adhesion was found. For the first time, in Turkey, the draft genome of Staphylococcus felis was obtained and made publicly accessible.
\end{abstract}

\section{Staphylococcus felis HARRANVET Suşunun Taslak Genom Dizisi}

\section{ÖZ}

Staphylococcus felis, kedilerin derisine kolonize olan stafilokok türlerinden biridir ve potansiyel bir fakültatif patojen olarak giderek daha fazla rapor edilmektedir. Yakın zamanda bir kedinin nekrotizan fasiit vakasından izole edilen Staphylococcus felis ( $S$. felis HARRANVET sușu olarak adlandırılan) tüm genom dizileme (WGS) ile karakterize edildi ve birleştirilmiş genom virülans ile antimikrobiyal direnç genleri yönünden in silico olarak analiz edildi. İzolat incelenen tüm antimikrobiyallere karșı duyarlı bulundu. Adhezyon ile ilișkili sınırlı sayıda virülans geni tespit edildi. Türkiye'de ilk kez, shotgun dizileme teknolojisi ile Staphylococcus felis'in genom sekans taslağı elde edildi ve erişime açı

hale getirildi.

\section{INTRODUCTION}

Although Staphylococcus spp. are known as part of natural microbiota of the skin, mucous membranes, alimentary and urogenital tracts of a wide range of mammals, they can also lead to a variety of clinical manifestations in humans and animals $(2,3,12)$. Staphylococcus felis ( $S$. felis) is one of commensal pathogen, regardless of health status of cats $(9,12)$. S. felis infections were associated with urinary tract infections, pyoder$\mathrm{ma}$, postoperative wound infections and otitis $(11,12)$. While the ability of $S$. felis isolates to produce urease is accepted an indication of potential urinary tract pathogen (11), their ability to form biofilm and produce proteolytic enzyme synthesis is accepted an indication of opportunistic skin pathogen (9).

Limited number of $S$. felis draft genome and complete genome are available in databases to date. Also, there is no study characterizing $S$. felis in Turkey. Therefore, we sequenced the complete genome of $S$. felis HARRANVET strain and investigated phenotypic and genotypic antimicrobial resistance profile.

\section{MATERIAL and METHODS}

\section{Isolation and Identification of S. felis}

The isolate was recovered from necrotizing fasciitis on a cat's head in Microbiology Laboratory, Faculty of Veterinary Medicine, Harran University. The isolate was preliminarily identified using phenotypic tests (Gram staining, catalase, coagulase testing) (6) and confirmed by MALDI-TOF MS and BLASTn analysis of $16 \mathrm{~S}$ rRNA sequencing using universal primers $(27 \mathrm{~F}-1492 \mathrm{R})$. The tube coagulase and slide agglutination tests were conducted using feline and rabbit plasma to determine the ability of the isolate to form clot formation (8).

\section{Antimicrobial Susceptibility Testing}

Antimicrobial susceptibility of the isolate was determined using disc diffusion method in accordance with Clinical Laboratory Standards Institute (CLSI) criteria (6), and the following discs were used: oxacillin $(1 \mu \mathrm{g})$, penicillin $(10 \mathrm{U})$, amoxicillin-clavulanic acid $(30 \mu \mathrm{g})$, trimethoprim-sulfamethoxazole (25 $\mu \mathrm{g})$, ciprofloxacin $(5 \mu \mathrm{g})$, clindamycin $(2 \mu \mathrm{g})$, gentamicin $(10$ $\mu \mathrm{g})$, chloramphenicol $(30 \mu \mathrm{g})$, rifampicin $(5 \mu \mathrm{g})$, tetracycline 
(30 $\mu \mathrm{g})$, linezolid (30 $\mu \mathrm{g})$, erythromycin (15), tigecycline (15 $\mu \mathrm{g})$, vancomycin $(30 \mu \mathrm{g})$, amikacin $(30 \mu \mathrm{g})$, fusidic acid $(10 \mu \mathrm{g})$, kanamycin $(30 \mu \mathrm{g})$, streptomycin $(10 \mu \mathrm{g})$, quinopristin-dalphopristin $(15 \mu \mathrm{g})$, ampicillin $(10 \mu \mathrm{g})$ and tobramycin $(10 \mu \mathrm{g})$. $S$. aureus ATCC 29213 was used as a positive control for coagulase and clumping factor tests and antimicrobial susceptibility testing as well.

\section{Coagulase Testing}

The tube coagulase test was conducted using both feline and rabbit plasma to determine the ability of the isolate to form clot formation. The isolate was accepted coagulasepositive if an immobile clot formed at the bottom of the tube after 4 hours incubation at $37^{\circ} \mathrm{C}$ or after overnight incubation at room temperature [6]. In addition, the slide agglutination test was used to assess the presence of clumping factor using rabbit and feline plasma. S. aureus ATCC 29213 was used as a positive control for coagulase and clumping factor test.

Whole-genome sequencing
The genome of $S$. felis HARRANVET strain was sequenced using the Illumina Novaseq platform with pair-end reads (PE 150) following the manufacturer's instructions (Illumina, San Diego, USA). Preprocessed reads were assembled using SPAdes Genome Assembler version 3.14.1 (1). The genome annotation was carried out with the NCBI Prokaryotic Genome Annotation Pipeline (PGAP) (http://www.ncbi.nlm. nih.gov/books/NBK174280/). The assembled genome was deposited at NCBI under accession no. JAEDAQ000000000. The sequenced reads were also assembled to $S$. felis ATTC 49168 using Bowtie2 alignment tool (10).

\section{Screening of antimicrobial resistance and virulence genes}

The assembled genome was screened in silico for acquired antimicrobial resistance and virulence genes, using openaccess bioinformatics website, the Center for Genomic Epidemiology (CGE) (https://cge.cbs.dtu.dk//services/). ResFinder v4.1 (15) and VirulenceFinder v2.0 (7) were used to identify acquired antimicrobial resistance genes and virulence genes, respectively. Additional virulence factors described for staphylococci, but not included in VirulenceFinder, were also

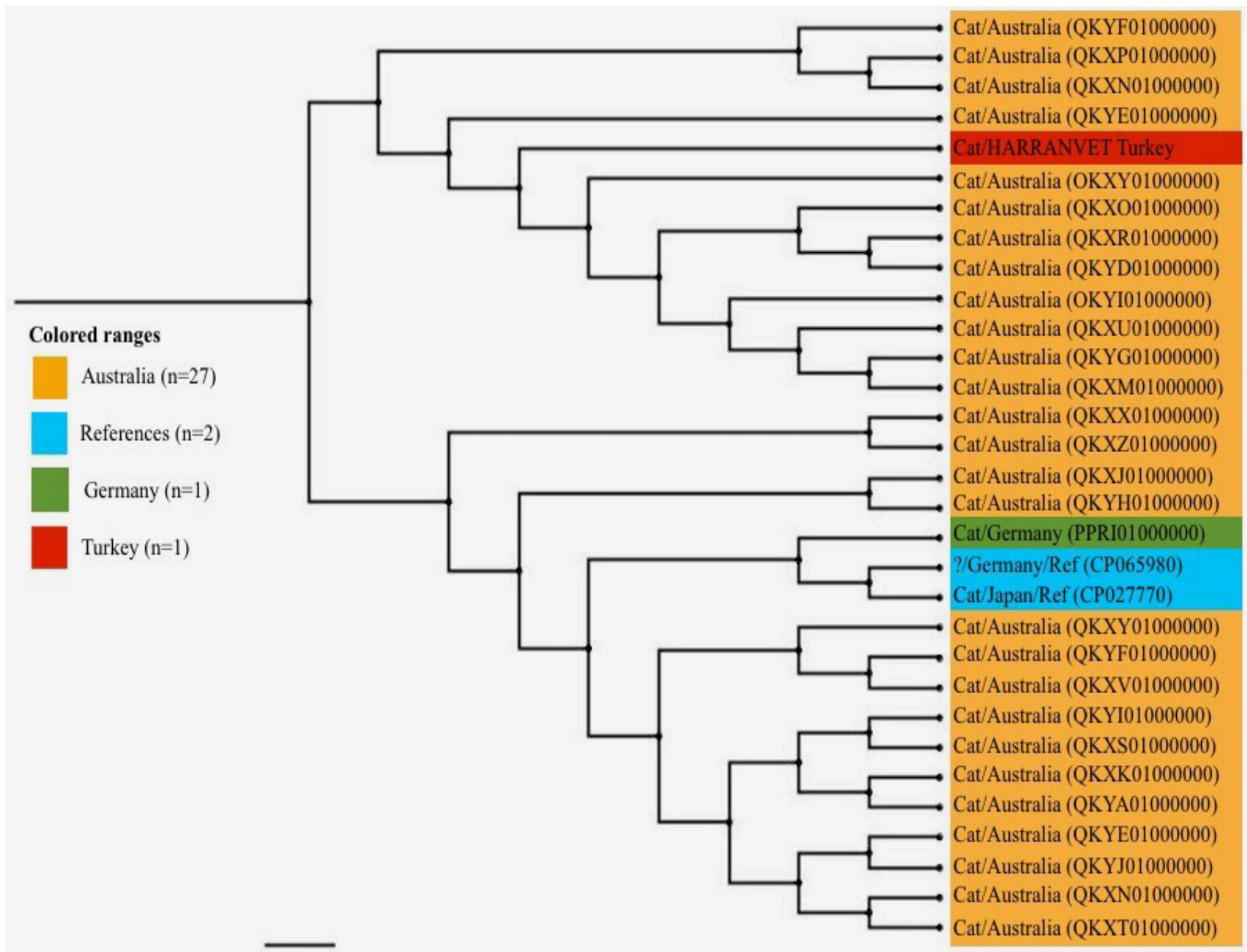

1.0

Figure 1. Maximum-likelihood phylogenetic tree based on $31 \mathrm{~S}$. felis genomes present in PATRIC databases. Geo

isolates is highlighted in different colours. GenBank accession numbers of each genome are given in parentheses. 
investigated using BLASTn tool of NCBI.

\section{Phylogenetic analysis}

Whole-genome sequences of $30 \mathrm{~S}$. felis isolates of cats and one isolate with unknown origin from different countries retrieved from the PATRIC S. felis database for phylogenetic analysis (4). GenBank accession numbers of genomes used in the phylogenetic comparison was seen in Figure 1. The tree was generated with maximum likelihood estimation methods. The evolutionary relationship between the $S$. felis strains was inferred by the aligned core-genomes using the program RAxML in PATRIC

\section{RESULTS}

\section{S. felis isolate}

The isolate was identified as $S$. felis by MALDI-TOF MS and BLASTn analysis of $16 \mathrm{~S}$ rRNA sequencing. The isolate was named $S$. felis HARRANVET strain.

\section{Antimicrobial resistance}

The isolate was found to be susceptible to all tested antimicrobials.

\section{Virulence factors}

In silico analysis of the assembled genome revealed absence of resistance genes from ResFinder database. The isolate did not harbor any virulence gene homologues deposited in the VirulenceFinder database. However, the isolate harbored putative virulence gene homologues for fibronectin/fibrinogen-binding protein (fnbB) and autolysin/adhesion (att).

\section{Genomic analysis}

The sequenced reads were assembled into a draft genome consisting 338 contigs, with the total length of 2,618,484 bp. The average $\mathrm{G}+\mathrm{C}$ content was 34.86147 . The assembled genome encoded 2,513 proteins and 54 transfer RNAs genes based on the annotation done at NCBI Prokaryotic Genome Annotation Pipeline (PGAP). On average, $88.73 \%$ of the sequence reads mapped to the 2,479,423 bp reference genome, S. felis ATCC 49168.

\section{Phylogenetic analysis}

Phylogenetic analysis based on 31 S. felis genomes present in the PATRIC database revealed two main clusters and several subclusters (Figure 1). The phylogenetic tree indicated that the $S$. felis HARRANVET strain was closely related with the isolates from Australian isolates.

\section{DISCUSSION}

The skin and mucous membranes of cats are colonized with staphylococcus species, with a dominance of coagulase-negative staphylococci (CoNS). Different interactions between staphylococci and the host may lead to development of symbiotic, commensal and opportunistic infections. Under favourable circumstances, opportunistic infections can occur and damage host tissues and organs (3).
Staphylococci can produce several virulence factors playing important role in its pathogenesis. The isolate did not show coagulase activity, which is one of the virulence factors produced by some Staphylococcus species. In a comprehensive study, Worthing et al. (14) detected coagulase activity only in an isolate $(1 / 27)$ with cat plasma, while they found the rest of the isolates being negative with both feline and rabbit plasma. In ter$\mathrm{ms}$ of other putative virulence factors investigated, the isolate harboured only fibronectin/fibrinogen-binding protein (fnbB) and autolysin (att) gene homologues, which are implicated in adhesion to host cells. The fnbB is a cell-bound protein that allows staphylococci to bind fibronectin, fibrinogen and elastin found on host cells, and is one of microbial cell surface protein receptors designated MSCRAMMs (5). The atl is a surface expressed hydrolase with diverse functions such as binding host matrices, involvement in biofilm formation and releasing cytoplasmic proteins from staphylococcal cell wall (13). Despite being searched for other virulence factors, other putative virulence genes were not determined in contrast to findings of Worthing et al (14), who detected genes responsible for both adhesion and toxin production. This drawback could be overcomed by using long-read sequence technology in future studies to elucidate other putative virulence determinants.

The isolate was susceptible to all the antimicrobials tested in the study. In contrast to other CoNS isolated from cats, it has been reported that $S$. felis strains had low level phenotypic antimicrobial resistance $(11,12,14)$. Possible reasons for low or no antimicrobial resistance observed among clinical $S$. felis isolates are explained in two ways: (i) fitness-cost of resistance can lead to reduced growth rate, competitive ability and virulence, compared with susceptible strains, (ii) the $S$. felis genome could have low plasticity to acquire a maintain mobile genetic elements (MGEs) conferring resistance (13).

As it can be seen in phylogenetic analysis (Figure), S. felis HARRANVET strain was placed in a cluster, closer to Australian isolates. The phylogenetic tree also showed high genetic diversity indicating host-adapted variations in the isolates.

In conclusion, for the first time, the draft genome of $S$. felis HARRANVET strain was obtained and made publicly available.

\section{DECLARATIONS}

\section{Ethics Approval}

This study does not present any ethical concerns.

\section{Conflict of Interest}

The authors declare that they have no competing interests.

\section{Author Contribution}

Idea, concept and design: O Aslantaş, O Keskin, K Büyükaltay

Data collection and analysis: O Aslantaş, O Keskin, K Büyükaltay, A Güllü Yücetepe

Drafting of the manuscript: O Aslantaş

Critical review: O Aslantaş, O Keskin, K Büyükaltay, A Güllü Yücetepe 


\section{Data Availability}

The data that support the findings of this study are available from the corresponding author upon reasonable request.

\section{Financial Support}

This research received no grant from any funding agency/sector

\section{REFERENCES}

1. Becker K, Heilmann C, Peters G. Coagulase-negative staphylococci. Clin Microbiol Rev, 2014; 27(4): 870-926.

2. Qekwana DN, Sebola D, Oguttu JW, Odoi A. Antimicrobial resistance patterns of Staphylococcus species isolated from cats presented at the veterinary academic hospital in South Africa. BMC Vet Res, 2017; 13:286.

3. Bierowiec K, Korzeniowska-Kowal A, Wzorek A, Rypuła K, Gamian A. Prevalence of Staphylococcus species colonization in healthy and sick cats. Biomed Res Int, 2019; 2019:4360525.

4. Kwaszewska A, Lisiecki P, Szemraj M, Szewczyk EM. Animal Staphylococcus felis with the potential to infect human skin. Med Dosw Mikrobiol, 2015; 67:69-78.

5. Litster A, Moss SM, Honnery M, Rees B, Trott DJ. Prevalence of bacterial species in cats with clinical signs of lower urinary tract disease: Recognition of Staphylococcus felis as a possible feline urinary tract pathogen. Vet Microbiol, 2007; 121(12):182-188.

6. Koneman EW, Allen SD, Janda WM, Schreckenberger PC, Winn WC. The gram-positive cocci. 1n, color atlas and textbook of diagnostic microbiology. 5th ed., Lippincott Raven Publishers, Philadelphia; 1997, p. 539-565.

7. CLSI. Performance Standards for Antimicrobial Susceptibility Testing; Twenty-Second Informational Supplement, CLSI document M100-S22, Wayne, PA: Clinical and Laboratory Standart Institute, 2012.

8. Bankevich A, Nurk S, Antipov D, Gurevich AA, Dvorkin M, Kulikov AS, et al. SPAdes: a new genome assembly algorithm and its applications to single-cell sequencing. J Comput Biol, 2012; 19:455-477.

9. Langmead B, Salzberg S: Fast gapped-read alignment with Bowtie 2. Nature Methods, 2012; 9:357-359.

10. Zankari E, Hasman H, Cosentino S, Vestergaard M, Rasmussen S, Lund $\mathrm{O}$, et al. Identification of acquired antimicrobial resistance genes. J Antimicrob Chemother, 2012; 67:2640-2644.

11. Joensen KG, Scheutz F, Lund O, Hasman H, Kaas RS, Nielsen EM, et al. Real-time whole-genome sequencing for routine typing, surveillance, and outbreak detection of verotoxigenic Escherichia coli. J Clin Microbiol, 2014; 52:15011510 .

12. Brettin T, Davis JJ, Disz T, EdwardsRA, GerdesS, OlsenGJ, et al. RASTtk: a modular and extensible implementation of the RAST algorithm for building custom annotation pipelines and annotating batches of genomes. Sci Rep, 2015;
$5: 8365$.

13. Worthing K, Pang S, Trott DJ, Abraham S, Coombs GW, Jordan D, et al. Characterisation of Staphylococcus felis isolated from cats using whole genome sequencing. Vet Microbiol, 2018; 222:98-104.

14. Burke FM, McCormack N, Rindi S, Speziale P, Foster JF. Fibronectin-binding protein B variation in Staphylococcus aureus. BMC Microbiol, 2010; 10:160.

15. Porayath C, Suresh MK, Biswas R, Nair BG, Mishra N, Pal S. Autolysin mediated adherence of Staphylococcus aureus with Fibronectin, Gelatin and Heparin. Int J Biol Macromol. 2018; 110:179-184. 